\title{
ENGINEERING RISK MANAGEMENT IN PERFORMANCE-BASED BUILDING ENVIRONMENTS
}

\author{
Nuno Marques ALMEIDA, Vitor SOUSA, Luís Alves DIAS, Fernando BRANCO \\ Department of Civil Engineering, Architecture and GeoResources Technical University of Lisbon - IST, \\ Av. Rovisco Pais 1049-001 Lisbon, Portugal
}

Received 31 Jul 2012; accepted 23 Oct 2012

\begin{abstract}
Nowadays, a wide range of stakeholders seek explicit performance and risk information on construction projects. These stakeholders include end-users, authorities, insurance companies and financial institutions, among others. They look for proof that engineering risks are being properly managed and that specified performance-based requirements are fulfilled throughout all stages of the project (e.g. technical requirements related to the building such as structural safety, structural serviceability, structural durability, fire safety, energy efficiency, or others). Such demonstration can be conveyed through statements of technical conformity, such as technical risk reports or engineering performance certificates. Statements of conformity are particularly valuable to make informed decisions associated with contractual or other legal warranties against building nonconformities. This paper describes the conceptual background and the methodologies undertaken to design and develop a management framework that enables recognition of the conformity assessment results of building projects. It also presents the outreach of this management framework throughout the planning, programming, design, construction and use phases of building projects. This paper also summarizes the wide range of practical implications and benefits of this management framework for authorities and official bodies, owners and their representatives, banks and insurance companies, conformity assessment bodies, designers, builders, suppliers and end-users.
\end{abstract}

Keywords: risk management, construction management, civil engineering, performance-based buildings, quality management, conformity assessment.

\section{Introduction}

Following the end of the Second World War, the construction sector, and the building subsector in particular, have been interpreting and adhering to three influent and interrelated conceptual approaches: 1) quality; 2) performance; and 3) risk. These conceptual approaches are the basis for several project management theories and practices, which are being used to support the complex task of consistently addressing the wide range of objectives that must be achieved throughout all activities and phases of construction projects in general, and building projects in particular, including the communication amongst stakeholders (ISO 10006).

The authors propose a solution to integrate the conceptual approaches of quality, performance and risk within the building subsector. The fundamental issues and complexities involved in such integration have been previously solved by the authors (Almeida et al. 2010a), together with a 1960-2010 review and discussion of the progresses of performance-based model codes and standards, standardized management principles, guidelines and systems, along with conformity assessment and auditing standards (Table 1). This discussion and literature review established the conceptual background for a new conceptual approach - Risk-Managed Performance-Based Building (RM-PBB) (Almeida et al. 2010b). This approach reinterprets and conciliates the principles of quality management, conformity assessment, performance-based building and risk management.

The proposed RM-PBB approach is grounded on an engineering perspective and aims at managing the whole range of requirements that relate to the technical performance of buildings. This approach complements conventional project management processes, such as those focused on time and cost. The underlying key principles of this approach are (Almeida et al. 2010a): 1) satisfaction of building end-users (society and individuals); 2) focus on the delivered product (whole building); 3) responsibility and liability of stakeholders participating in the building project; 4) end-user protection against non-conforming buildings; and 5) conveyance of information related with building technical requirements.

Corresponding author: Nuno Marques Almeida

E-mail: nunomarquesalmeida@tecnico.ulisboa.pt 
This paper aims to present a management framework that enables the practical application of the RM-PBB principles to the construction sector as a whole, and to the building subsector in particular, at transnational (e.g. EU member states level), national, regional and/or local levels.

Section 1 of this paper describes the methodology that was used to attain the final version of the RM-PBB framework. Section 2 summarizes the main benefits and practical implications of this framework for building projects' major stakeholders, such as authorities, owners, developers, end-users, banks and financial investors, amongst others. It also demonstrates how this framework may contribute to improving legal compliance or otherwise stated technical requirements throughout the planning, programming, design, construction and use phases of building projects. Following that, acknowledgments are presented. Bibliographic references and standards and guidelines which are mentioned throughout the text are presented in two separate subsections.

\section{A framework for managing engineering risks in performance-based environments}

This section describes the designing and developing of a framework for managing engineering risks in performance-based environments - the RM-PBB framework. Namely, it decribes the methodology undertaken throughout the design and development processes (sub-section 1.1) and its underlying premisses (sub-section 1.2). It also describes the selecion, analysis, grouping and conciliation of the inputs to the design process (sub-sections 1.3 and 1.4) and presents a review and a verification of the resulting output (sub-sections 1.5 and 1.6). In the end, the developing process is also adressed (sub-section 1.7).

\subsection{Methodology for designing and developing the framework}

The quality, performance and risk approaches overlap and complement each other (Sousa et al. 2012; Srdic, Selih 2011; Almeida et al. 2010a). Moreover, if taken from an engineering perspective, they can be combined and successfully applied to building projects by means of a new RM-PBB approach. However, transferring the conceptual RM-PBB approach into practice requires an appropriate management framework.

Following the methodological options for research focused on the creation of new scientific knowledge in a competitive business environment, the methodology for designing and developing the framework for

Table 1. Issues covered by the authors in the 1960-2000 literature review

\begin{tabular}{|c|c|c|c|c|c|}
\hline Issues & Initiatives & $\begin{array}{l}\text { Proposing } \\
\text { institutions }\end{array}$ & Reference document & Provenience & Conceptual approach \\
\hline \multirow{7}{*}{$\begin{array}{l}\text { Performance- } \\
\text { based model } \\
\text { codes and } \\
\text { standards }\end{array}$} & Nordic model & NKB & NKB (1978) & Regulatory & Performance \\
\hline & Eighth-tiered model & IRCC & Meacham (2004a) & Regulatory & $\begin{array}{l}\text { Performance and } \\
\text { risk }\end{array}$ \\
\hline & $\begin{array}{l}\text { Performance system } \\
\text { model }\end{array}$ & CIB TG37 & CIB (2004) & $\begin{array}{l}\text { Non-regulatory with } \\
\text { regulatory influence }\end{array}$ & $\begin{array}{l}\text { Performance and } \\
\text { risk }\end{array}$ \\
\hline & $\begin{array}{l}\text { Description of } \\
\text { performance of } \\
\text { houses }\end{array}$ & ISO & $\begin{array}{l}\text { ISO } 22539 \text { and ISO } \\
15928\end{array}$ & $\begin{array}{l}\text { Non-regulatory with } \\
\text { regulatory influence }\end{array}$ & $\begin{array}{l}\text { Performance and } \\
\text { risk }\end{array}$ \\
\hline & Systems approach & NBS & $\begin{array}{l}\text { Hattis, Becker } \\
(2001)\end{array}$ & Non-regulatory & Performance \\
\hline & $\begin{array}{l}\text { Whole building } \\
\text { functionality and } \\
\text { serviceability }\end{array}$ & ASTM & ASTM (2000) & Non-regulatory & Performance \\
\hline & $\begin{array}{l}\text { Functional and user } \\
\text { requirements and } \\
\text { performance of } \\
\text { buildings }\end{array}$ & ISO & ISO 11863 & Non-regulatory & Performance \\
\hline \multirow{5}{*}{$\begin{array}{l}\text { Standardized } \\
\text { management } \\
\text { principles, } \\
\text { guidelines and } \\
\text { systems }\end{array}$} & Quality management & ISO & ISO 9000 series & Non-regulatory & Quality \\
\hline & $\begin{array}{l}\text { Environmental } \\
\text { management }\end{array}$ & ISO & ISO 14000 series & Non-regulatory & Quality \\
\hline & OSH management & OIT & ILO-OSH: 2001 & Non-regulatory & Quality \\
\hline & $\begin{array}{l}\text { Project quality } \\
\text { management }\end{array}$ & ISO & ISO 10006 & Non-regulatory & Quality and risk \\
\hline & Risk management & ISO & ISO 31000 & Non-regulatory & Quality and risk \\
\hline \multirow{2}{*}{$\begin{array}{l}\text { International } \\
\text { conformity } \\
\text { assessment } \\
\text { and auditing } \\
\text { standards }\end{array}$} & $\begin{array}{l}\text { Conformity } \\
\text { assessment }\end{array}$ & ISO & ISO 17000 series & Non-regulatory & Quality \\
\hline & Auditing & ISO & ISO 19011 & Non-regulatory & Quality \\
\hline
\end{tabular}


managing engineering risks in performance-based building environments was based on a combination of the systems approach and the actors approach (Arbnor, Bjerke 2009; Olsson 2006).

The systems approach was used for the design process of the framework, in which the inputs were taken from system analysis. The resulting output of this initial process was a preliminary system model capable of describing, explaining and understanding the building subsector. The systems approach admits refinements and further developments of the preliminary outputs, just as the process approach promoted in ISO 9000 standards admits that the effectiveness of quality management systems may be improved.

The refinements and adjustments of the preliminary outputs were undertaken by using the actors approachan approach in which individual motivations of the various stakeholders are taken into consideration in order to gain new insights. These new insights were used in the development of the final form of the framework and for establishing its seven interrelated elements.

The methodology for designing and developing the framework followed the design and development requirements of the ISO 9001 quality management standard (7.3), namely those related with design and development planning (7.3.1), design and development inputs (7.3.2), design and development outputs (7.3.3), design and development review (7.3.4), design and development verification (7.3.5), design and development validation (7.3.6), and control of design and development changes (7.3.7). Hence, the methodology involved the following steps:

- establishing the premises for designing and developing the framework: these premises safeguard and enable the demonstration of the robustness of the proposed framework;

- selecting the inputs for design and development: the main selection criteria was to give primacy to wellestablished initiatives deriving from the conceptual approaches of quality, performance and risk;

- analysing, grouping and conciliating the inputs for designing the framework: the most relevant aspects of the selected inputs were analysed in order to detect complementarities, organized into three groups and conciliated into a first proposal of the envisaged framework;

- reviewing the proposed framework: the output of the design process was submitted to an iterative review process for refining the inter-relations subsisting amongst the components and the elements of the proposed RM-PBB framework;

- verifying the robustness of the proposed framework: an examination of the design process output was undertaken in order to asses if the resulting framework held the intended robustness; and

- developing the proposed framework: upon termination of the design process, the seven elements of the proposed framework were subject to specific developments in order to cope with the particular contexts in which they are to be applied.

\subsection{Establishing the premises for designing and developing the framework}

In order to control the design and development of the framework, a set of premises were established. These premises were used as guiding principles to be applied whenever a necessity of choice arose during the design and development process, in order to ensure and enable the demonstration of the robustness of the final outcome. The explanation for the robustness of the final outcome is presented in Table 2. This explanation has been adapted from FRISCO's guiding principles, options and choices for setting up a framework of information system concepts (IFIC 1998).

\subsection{Selecting the inputs for designing the framework}

The selected inputs for designing the framework gather international consensus and derive from conceptual approaches such as those of quality, performance and risk. Hence, the proposed framework is grounded on the policies, procedures and practices of relevant initiatives that were originated from the performance-based building concept, including performance-based model codes and standards such as the NKB Nordic Model (NKB 1978), the IRCC eighth-tiered model (Meacham 2004a), the CIB TG 37 Performance System Model (CIB 2004), the NBS Systems Approach (Hattis, Becker 2001), the ASTM Standards on Whole Building Functionality and

Table 2. Premises for designing and developing the framework

\begin{tabular}{ll}
\hline $\begin{array}{l}\text { Robustness } \\
\text { characteristics }\end{array}$ & $\begin{array}{l}\text { Guiding principles for designing and } \\
\text { developing the framework }\end{array}$ \\
\hline $\begin{array}{l}\text { Global } \\
\text { consistency }\end{array}$ & $\begin{array}{l}\text { Mitigate independent and incompatible } \\
\text { portions of the framework by } \\
\text { determining formal and well-established } \\
\text { relations amongst the portions. }\end{array}$ \\
\hline Generality & $\begin{array}{l}\text { The resulting framework should be as } \\
\text { generic as possible, but catering for } \\
\text { details and specificities of various fields } \\
\text { of expertise. }\end{array}$ \\
\hline Simplicity & $\begin{array}{l}\text { The whole and the parts of the resulting } \\
\text { framework should be as simple } \\
\text { and straightforward as possible (no } \\
\text { unnecessary complexity). }\end{array}$ \\
\hline Correspondence \\
(with existing & $\begin{array}{l}\text { Use well established concepts from } \\
\text { relevant management and engineering } \\
\text { disciplines (avoid isolated conceptual } \\
\text { outcomes that are incompatible with } \\
\text { related disciplines), but only to the } \\
\text { absolutely necessary level of detail. }\end{array}$ \\
\hline Adaptability & $\begin{array}{l}\text { Recognize the inevitable limitation } \\
\text { in scope of the resulting framework, } \\
\text { which should nevertheless serve as } \\
\text { a conceptual foundation that can be } \\
\text { adapted and extended to various scopes } \\
\text { of application. }\end{array}$ \\
\hline & \\
\hline &
\end{tabular}


Serviceability (ASTM 2000) and the subsequent ISO 11863 standard on functional and user requirements and performance of buildings and building-related facilities, and also the ISO 15928 standard for the description of performance of houses (ISO/PAS 22539).

The proposed framework is also grounded in the most important standardized management principles, guidelines and systems. Namely, it takes into due consideration the requirements of the ISO 9001 for quality management systems, the ISO 14001 for environmental management systems, the ILO-OSH: 2001 for occupational safety and health management systems, the ISO 31000 for standardized risk management and the ISO 10006 for quality management in projects. The framework is also compatible with the essential features of the ISO 21500 guide for project management, which is presently under development.

Finally, the proposed framework is also based on internationally recognized principles of conformity assessment, in particular those established by the ISO 17000 series of standards, and also the auditing principles laid down by ISO 19011 .

The various initiatives that have been used as inputs for designing the final version of the proposed framework are presented in Table 3 .

\subsection{Analysing, grouping and conciliating the inputs for designing the framework}

Figure 1 depicts the historical progress and relations between the various initiatives that have been used as inputs for designing the final version of the framework. These initiatives may be grouped into: 1) performance-based inputs (group 1); 2) standardized management principles, guidelines and standards (group 2) and; 3 ) conformity assessment and auditing standards (group 3). All these groups of initiatives, excluding the ISO 17000 series of standards on conformity assessment, have been explained and analysed previously by the authors (Almeida et al. 2010a).

Performance-based model codes and standards (group 1) ensure common features in terms of the hierarchical structure, as well as the underlining philosophy and targets (Ang et al. 2005; Becker, Foliente 2005; Bukowski et al. 2001; Hattis, Becker 2001; Pilzer 2005; Szigeti, Davis 2005a; Visscher, Meijer 2006). Typically, the performance-based inputs are formatted into a hierarchical structure in which the top level expresses qualitative objectives that break down into various levels of sub-objectives and quantitative measures, which may also incorporate 'deemed-to-comply' prescriptive solutions. This format was adopted in performance-based building regulations and codes of various countries (e.g. Australia, Austria, Singapore, China, New Zealand, USA, Canada, Japan, Norway).

The quality and the risk approaches strengthen and complement the performance-based approach (Almeida et al. 2010a), namely regarding liability concerns arising from possible failures of a building that is designed according to performance-based principles (CIB 2004). In fact, it is not surprising that many countries are nowadays

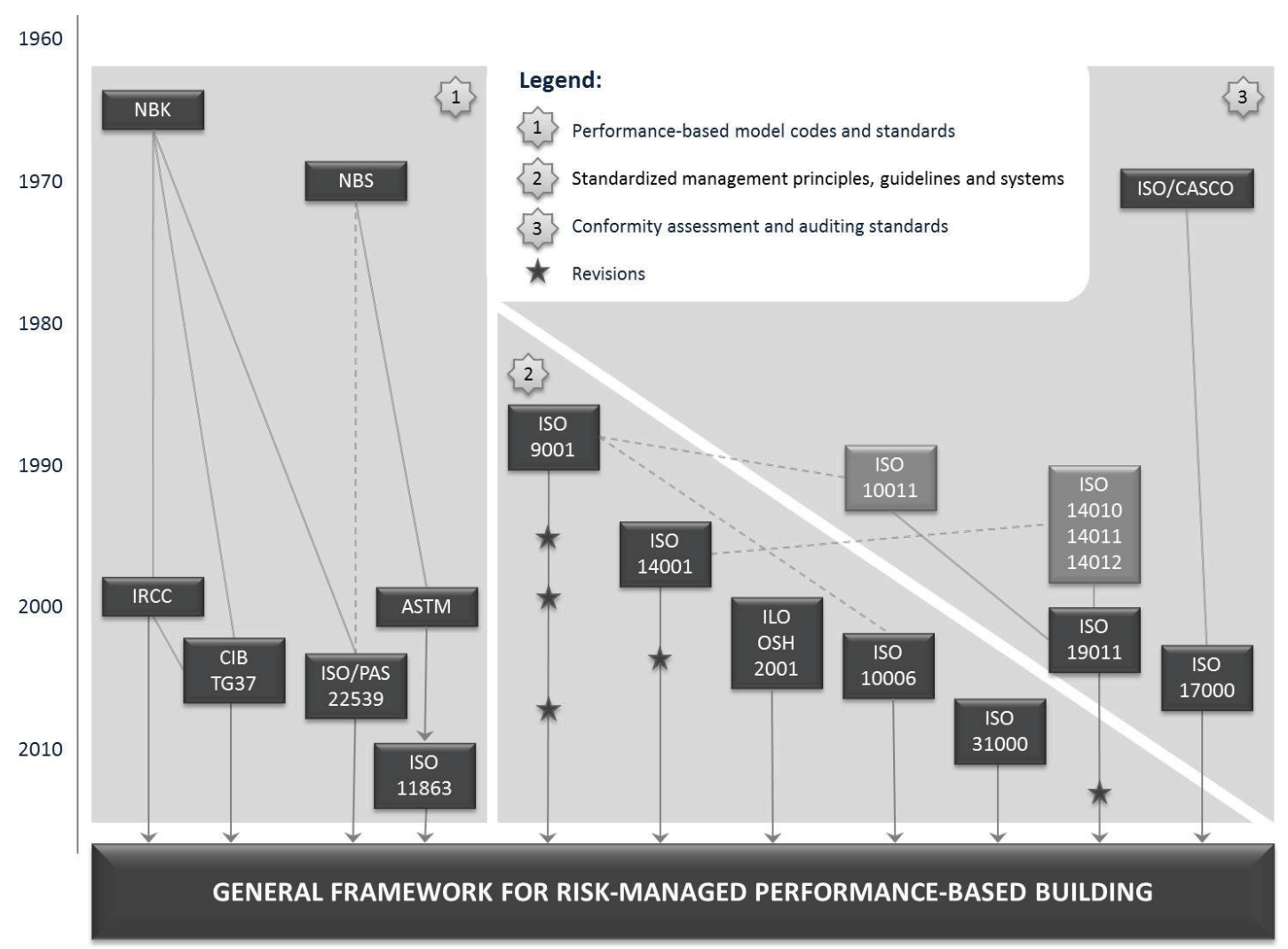

Fig. 1. Background of the final version of the proposed framework 


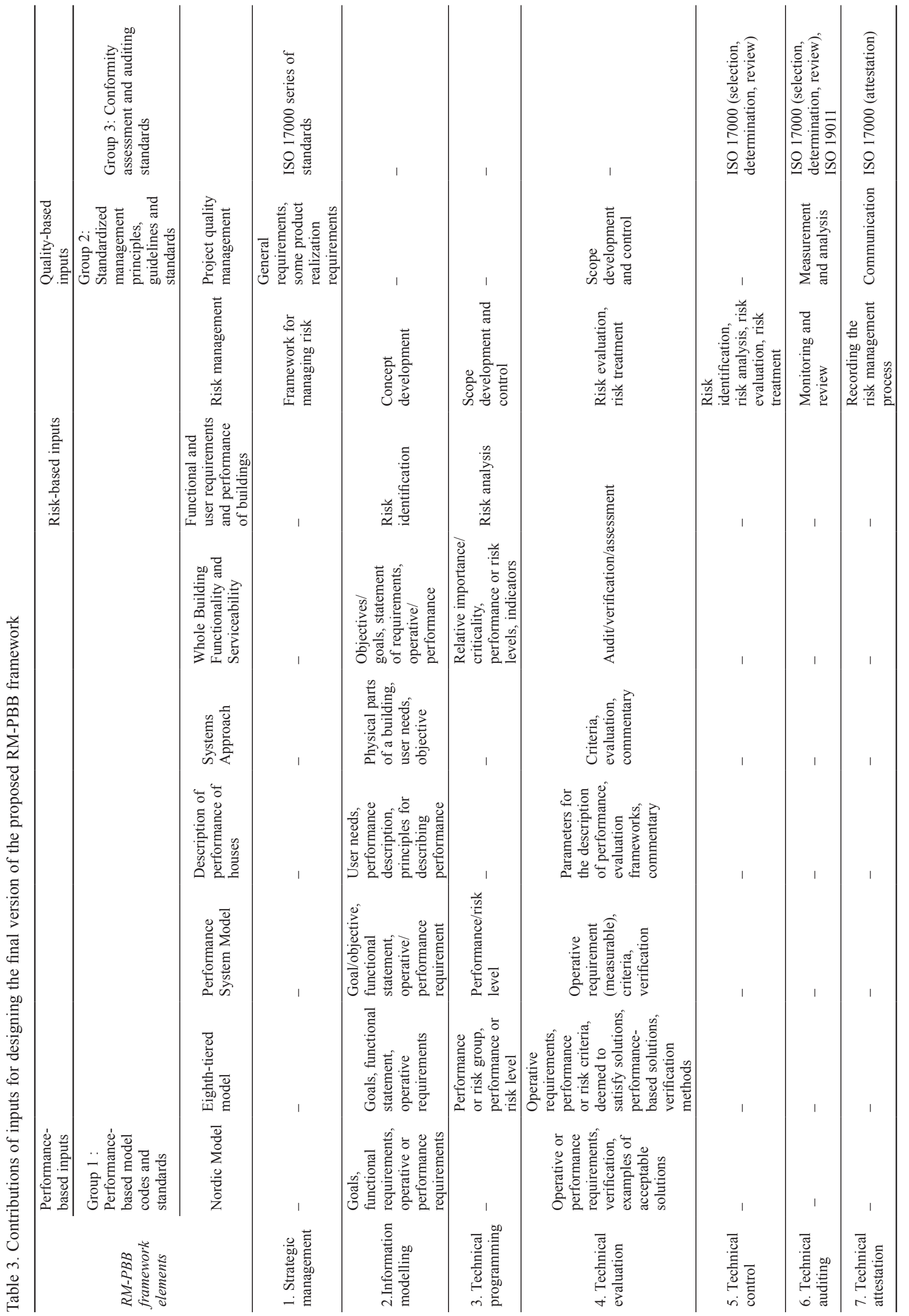


developing regulatory environments with the assistance of risk-informed performance-based regulations (IRCC 2010) and performance-based standards (ISO/ PAS 22539; ISO 15928; Walker et al. 2010). The latter support the development of quality and risk management tools for dealing with the possibility of building failures. These tools are useful to assist end-users, authorities, financial institutions and insurance companies (or other risk takers of the kind) to support decisions based on information on the level of quality that is actually achieved by the delivered building product (expressed in terms of measurable performance and risk levels). There are several quality-based and risk-based standardized management principles, guidelines and standards (group 2) that may assist the development of such tools and, moreover, the issuance of an independent third-party demonstration of conformity, expressed in terms of engineering performance and risk levels.

Independent third-party demonstrations services may be provided by internationally or nationally recognized conformity assessment bodies. The ISO 17000 series of standards, together with the ISO 19011 auditing standard, constitutes an infra-structure (group 3) that aims at safeguarding societal values, such as the transparency, trust and respect, towards the development of stakeholder credibility, confidence and acceptance of the results of the activities performed by those bodies (ISO 2010). Figure 2 depicts the three synthetic functions into which all conformity assessment activities may be framed (ISO 17000):

- selection: preparation activities aiming at the collection or production of all the information and input needed for the subsequent determination function (e.g. sampling; selection of requirements, testing or inspection methods and scope of testing to be covered by laboratory accreditation; selection of locations or individuals to perform determination activities);

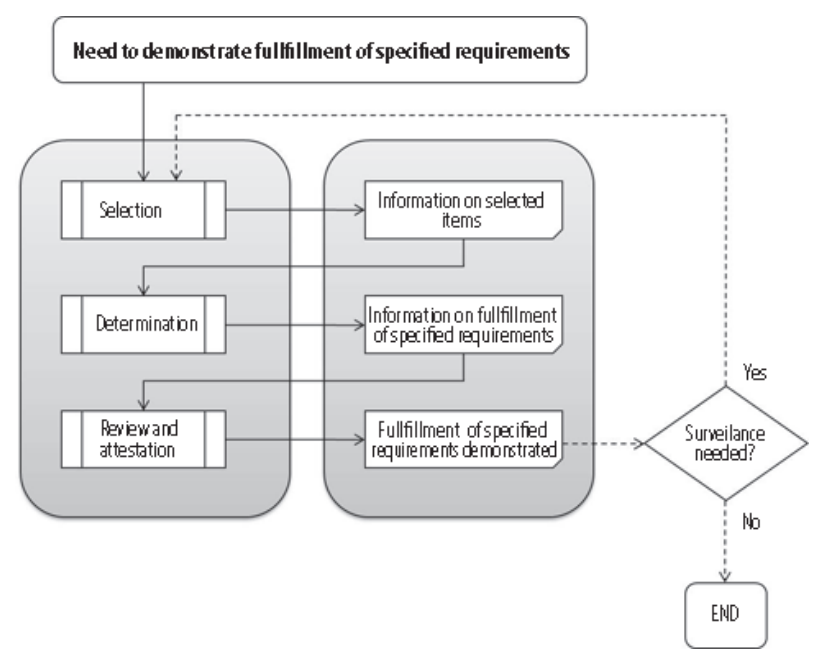

Fig. 2. Functional approach to conformity assessment (ISO 17000)
- determination: activities which are undertaken to develop complete information regarding the fulfilment of specified requirements by the object of conformity assessment or its sample (e.g. testing, inspection, audit, peer assessment, examination or analysis of a design or other descriptive information);

- review and attestation: the final stages of checking the structured output of determination activities, before taking the decision as to whether or not the object of conformity assessment has been reliably demonstrated to fulfil the specified requirements, conducing to a "statement", or other means of communicating, that fulfilment of the specified requirements has been demonstrated, in a way that most readily reaches all of the potential users (e.g. declaration; certification; accreditation).

Conformity assessment may not end when attestation is performed, if a systematic iteration of the three synthetic functions is required to maintain the validity of the statement resulting from attestation. These iterations are driven by the needs of the users. For example, the levels of building performance are affected throughout its entire lifetime - thus the conformity status upon completion of the building may change over time. This means that a statement of conformity which is first issued upon completion cannot remain valid if the fulfilment of the specified requirements is affected.

The ISO 17000 series of standards is developed and maintained by the ISO/CASCO committee since 1970 and cover a wide range of conformity assessment activities. A list of some of the main guidelines and standards published by the ISO/CASCO committee, as well as their scope of application, is presented in Table 4 .

The convergence of these 3 groups of inputs has been previously demonstrated by the authors (Almeida et al. 2010a), as well as their conciliation into the proposed general framework. A review of the final version of the proposed framework is presented next.

\subsection{Review of the proposed framework}

The analysis of the selected inputs set the ground for forming three groups of inputs: 1) a first group of inputs that merges performance-based model codes and standards; 2) a second group that integrates standardized management principles, guidelines and systems; and 3) a third group that enables the incorporation of conformity assessment and auditing standards.

Efforts were undertaken towards conciliating the extrinsic differences and the intrinsic complementarities of these three groups (Almeida et al. 2010a). These efforts led to a first framework proposal (Almeida et al. 2010b), which, since then, has been further refined through an iterative process of reviewing the interrelations subsisting amongst the components and the elements of the proposed framework.

Fundamentally, the framework is twofold, as shown in Figure 3. It comprises a strategic and an operational component. The strategic component includes a single element (element 1: strategic management) that follows a 
Table 4. List of international conformity assessment guidelines and standards

\begin{tabular}{ll}
\hline Subject & Guidelines and standards \\
\hline $\begin{array}{l}\text { Vocabulary, general principles and common elements of } \\
\text { conformity assessment }\end{array}$ & $\begin{array}{l}\text { ISO 17000, ISO 17001, ISO 17002, ISO 17002, ISO 17003, } \\
\text { ISO 17004, ISO 17005 }\end{array}$ \\
\hline $\begin{array}{l}\text { Guidance for drafting normative documents suitable for use } \\
\text { for conformity assessment }\end{array}$ & ISO 17007 \\
\hline Certification of product, processes and services & $\begin{array}{l}\text { ISO 17065, ISO 17067, ISO Guide 23, ISO Guide 28, ISO } \\
\text { Guide 53 }\end{array}$ \\
\hline Code of good practice & ISO Guide 60 \\
\hline Mutual recognition arrangements & ISO Guide 68 \\
\hline Accreditation & ISO 17011 \\
\hline Auditing and certification & ISO 17021, ISO 17022, ISO 19011 \\
\hline Inspection & ISO 17020 \\
\hline Certification of persons & ISO 17024 \\
\hline Testing and calibration & ISO 17025, ISO 17043 \\
\hline Third-party marks of conformity & ISO Guide 27, ISO 17030 \\
\hline Peer assessment & ISO 17040 \\
\hline Supplier's declaration of conformity & ISO 17050-1, ISO 17050-2 \\
\hline
\end{tabular}

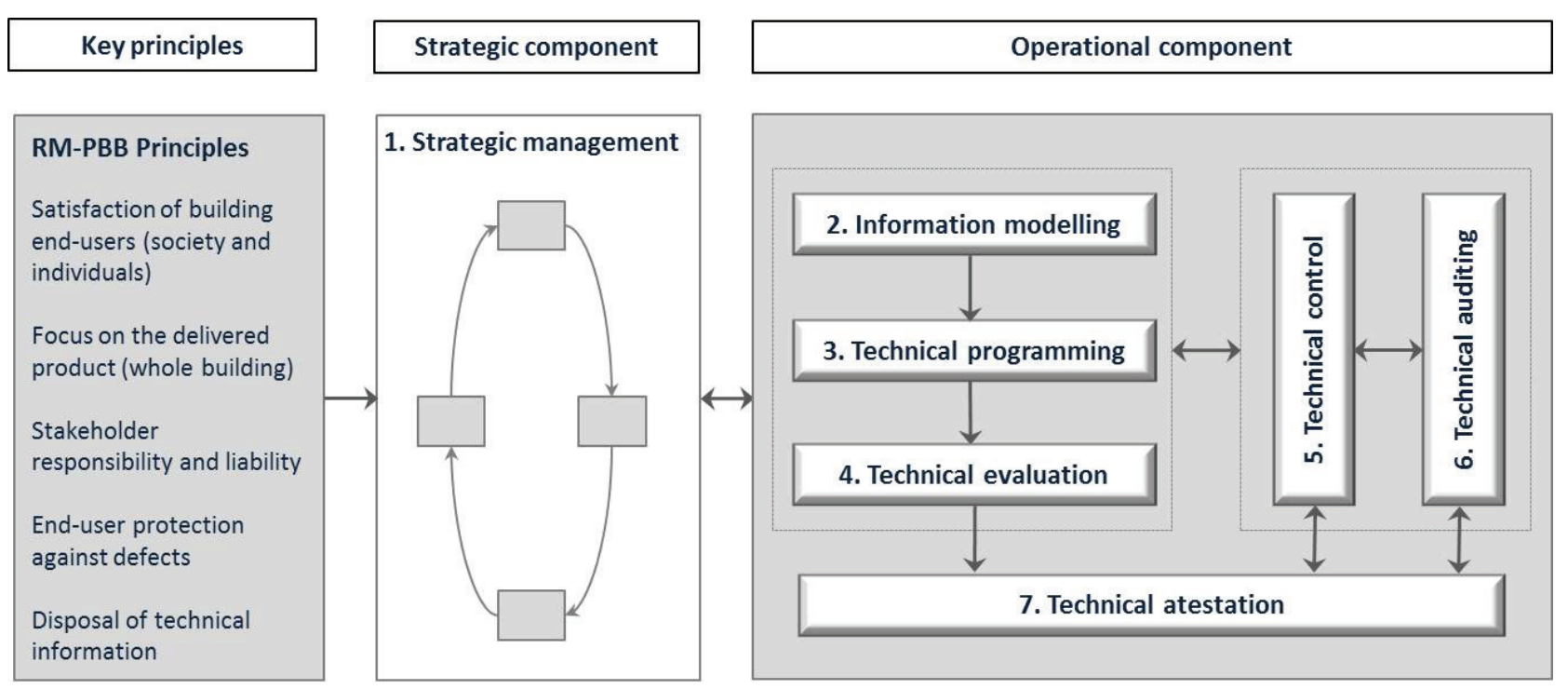

Fig. 3. Final version of a framework for managing the engineering risks of performance-based buildings

plan-do-check-act cycle (Deming cycle) in order to establish the basis (act), the planning (plan) and the organizational dispositions needed for the implementation of the RM-PBB approach (do), as well as for the monitoring and the reviewing (check) and the continual improvement of such implementation. The operational component comprises six elements (elements 2 to 7: information modelling, technical programming, technical evaluation, techical control, technical auditing and technical attestation) promoting the systematic application of the RM-PBB principles to the activities of the successive phases of a building project. These elements support activities such as the development and publication of technical regulations, the marketing of building projects, the design and construction of the performance-based buildings, the commissioning and testing of the constructed facilities and the issuance of decision supportive statements of conformity.

The practical implications of these two components and its seven elements for the different stakeholders, throughout the various stages of a building project, are further described in the concluding remarks of this paper (Section 2). Additional details of the seven elements are presented in Almeida (2011), together with an example of application of the proposed framework to manage the engineering risks of performance-based building structures.

\subsection{Verifying the robustness of the proposed framework}

The background hypothesis for designing the framework was that overlapping conceptual approaches - such as 
those of quality, performance and risk - could be taken from an engineering perspective and incorporated into a general management framework applicable to building projects (Almeida et al. 2010a).

The robust solution is a result of the combination of various initiatives present in these three conceptual approaches (Tables 1 and 3). The robustness of the framework was secured throughout its designing process. Table 5 shows that all relevant decisions and choices made along the different stages of the design process adhered to a set of pre-established guiding principles and, thus, demonstrates that the resulting framework holds the desired

Table 5. Verification of the robustness of the proposed RMPBB framework

\begin{tabular}{ll}
\hline Robustness & Contribution of design stages to the \\
characteristics & robustness of the output \\
\hline & $\begin{array}{l}\text { The careful selection of inputs for } \\
\text { designing the framework assures global } \\
\text { consistency in as much as it safeguards } \\
\text { the design output from the influence } \\
\text { of initiatives which have not been } \\
\text { thoroughly tested, implemented or } \\
\text { discussed. }\end{array}$ \\
\hline $\begin{array}{l}\text { The analysis of the inputs for designing } \\
\text { the framework enhances global }\end{array}$ \\
consistency by unveiling underlying \\
complementarities between the different \\
inputs and, thus, by conforming links \\
between the elements of the framework.
\end{tabular}

characteristics of robustness (see Table 2 for a correspondence between the guiding principles and the associated robustness characteristics of global consistency, generality, simplicity, correspondence with existing initiatives and adaptability).

\subsection{Developing the proposed framework}

The general goal of the proposed framework is to enable the practical application of the RM-PBB approach and principles to the building sector. However, the first output of the design process is a proposal that is applicable to building projects only in general terms. Hence, each element must be developed and detailed in order to be applied to specific engineering contexts.

The proposed framework is generally applicable to the full spectrum of technical requirements of publically or privately promoted building projects, whether the intended use of such buildings is residential or nonresidential. In fact, this framework can be used to manage the increasing array of legal aspects for products, processes and services, including those related with safety and health, the preservation of the environment, and other individual or societal requirements that are not explicitly regulated or otherwise stated.

The seven elements of the proposed framework are compatible with the generic guidelines of ISO/PAS 22539 and thus articulate with all the performance-based requirements addressed in the various parts ISO 15928 international series of standards, including those that have correspondence with the basic performance-based requirements for construction works laid down by the Construction Products Regulation (Regulation EU No 305/2011 of the European Parliament and of the Council of 9 March 2011). Table 6 presents the correspondences between the performance-based requirements of these two documents.

Table 6. Correspondences between ISO 15928 attributes and CPR basic requirements

\begin{tabular}{ll}
\hline $\begin{array}{l}\text { Attributes covered by the } \\
\text { ISO 15928 standard for the } \\
\text { description of performance of } \\
\text { houses }\end{array}$ & $\begin{array}{l}\text { Basic performance } \\
\text { requirements laid down by } \\
\text { the Construction Products } \\
\text { Regulation (CE Marking) }\end{array}$ \\
\hline $\begin{array}{l}\text { Structural safety } \\
\text { (ISO 15928-1:2003) }\end{array}$ & $\begin{array}{l}\text { 1. Mechanical resistance } \\
\text { and stability }\end{array}$ \\
$\begin{array}{l}\text { Structural serviceability } \\
\text { Structural durability } \\
\text { (ISO 15928-3:2009) }\end{array}$ & \\
\hline Fire safety (ISO 15928-4:2011) & \begin{tabular}{l} 
2. Safety in case of fire \\
\hline-
\end{tabular} \\
\hline $\begin{array}{l}\text { 3. Hygiene, health and the } \\
\text { environment }\end{array}$ \\
\hline $\begin{array}{l}\text { 4. Safety and accessibility } \\
\text { in use }\end{array}$ \\
\hline $\begin{array}{l}\text { Operating energy } \\
\text { (ISO 15928-5:2013) }\end{array}$ & $\begin{array}{l}\text { 6. Energy economy and } \\
\text { heat retention }\end{array}$ \\
\hline $\begin{array}{l}\text { Sustainability (to be submitted } \\
\text { as a work item) }\end{array}$ & $\begin{array}{l}\text { 7. Sustainable use of } \\
\text { natural resources }\end{array}$ \\
\hline
\end{tabular}


In the case of the Construction Products Regulation, it must be noted that it states that "construction works as a whole and in their separate parts must be fit for their intended use (...) throughout the life cycle of the works" and also that when "subject to normal maintenance, construction works must satisfy these basic [performance] requirements (...) for an economically reasonable working life." In this singular context, the quality of a building may thus be interpreted as the degree to which the building as whole adheres to the seven basic requirements laid down by the Construction Products Regulation. However, this particular regulation only addresses construction products for incorporation in a permanent manner in buildings and civil engineering works, or parts thereof, and not the construction as a whole.

This means that construction products that comply with this particular regulation (and thus bear the CE Marking) do not cause a negative effect upon the basic performance requirements of a building into which they are incorporated. However, one cannot necessarily deduce the same conclusion regarding the building as a whole, for the building as a whole is a complex dynamic system (Gielingh 2008). Complex dynamic systems like buildings embrace several interacting physical subsystems (e.g. foundations, superstructures, plumbing, roofing), which in their turn are composed by building elements (e.g. beams, slabs, pipes) that function in an isolated manner or in combination with other elements, within or without the same building subsystem, and, finally, by construction products (e.g. concrete, etc.), which are manufactured, supplied and processed towards being incorporated in a permanent manner in those buildings elements (Fig. 4).

In other terms, even if all construction products used in a building project bear CE Marking (or any other type of demonstration of conformity), there are still planning, design, construction and maintenance procedures that must be properly managed and executed so that all basic performance requirements of a building may be fulfilled. The proposed framework covers all such relevant procedures and may be used by the management and the engineering practitioners in their daily practice towards assuring and attesting that buildings as a whole comply with regulated or otherwise stated performance requirements. Figure 4 illustrates the outreach of the proposed framework and its global development, as compared to the narrower outreach of the mandatory CE Marking (laid down by the Construction Products Regulation).

\section{Conclusions}

Several authors have identified the need to strengthen decision making capacity of the various stakeholders in the building sector (Lützkendorf, Lorenz 2006), and hence strengthen the capacity for responsibility of these actors in face of an ever-increasing global market place (IRCC 2010).

Table 7 presents a suggested hierarchy of responsibility of the most relevant stakeholders interacting throughout all phases of a building project linked to the seven elements of the proposed framework.

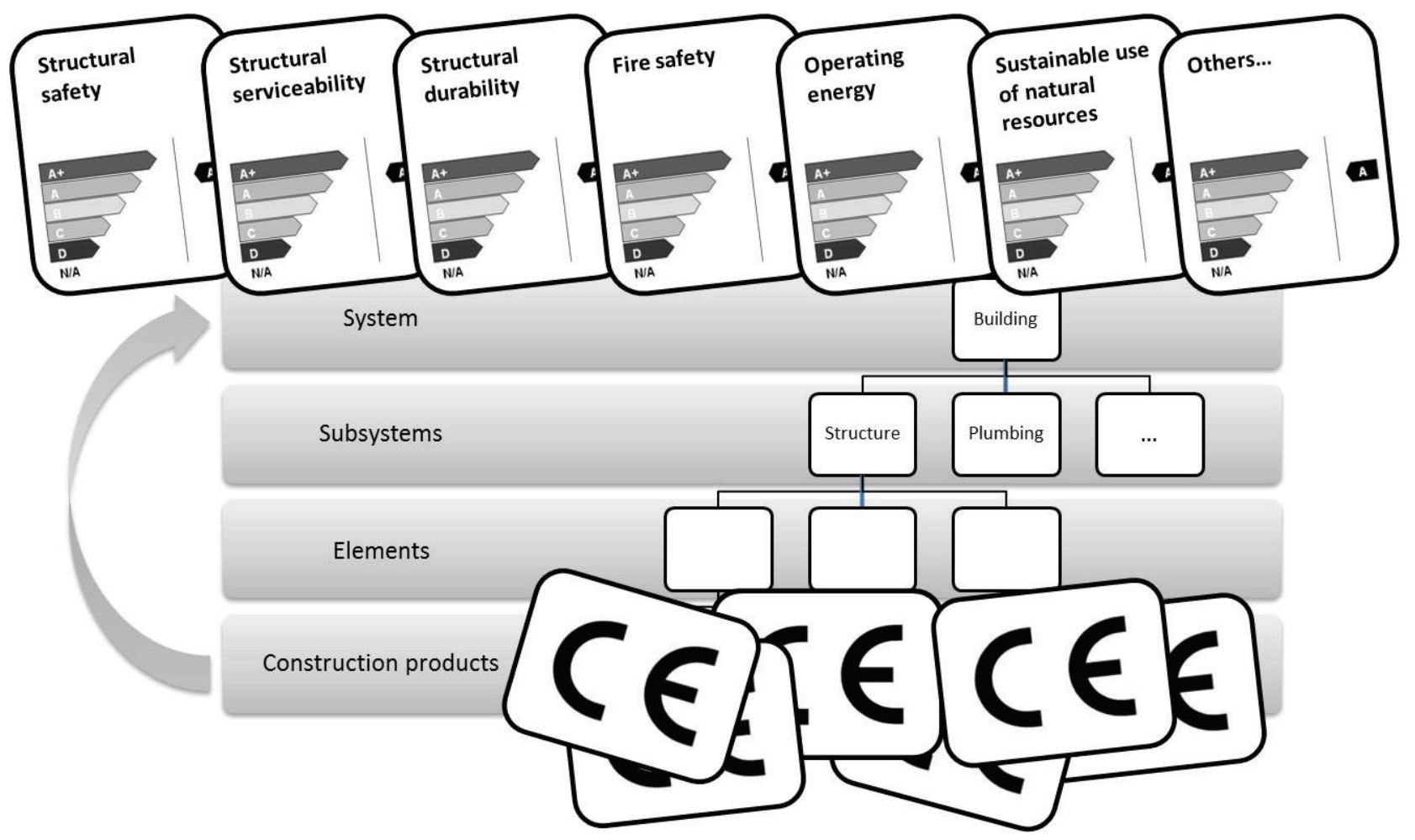

Fig. 4. Outreach of the proposed framework 
Table 7. Applicability of the seven elements of the proposed framework

\begin{tabular}{|c|c|c|c|c|c|}
\hline \multirow{2}{*}{$\begin{array}{l}\text { Hierarchy of responsibility of } \\
\text { participant stakeholders in a } \\
\text { building project }\end{array}$} & \multicolumn{5}{|c|}{ Phases of the building project } \\
\hline & Strategic planning & Programming & Design & Construction & Use \\
\hline authorities and official bodies & $1,2,3$ & & & & \\
\hline $\begin{array}{l}\text { owners and their } \\
\text { representatives }\end{array}$ & & 3 & 6,7 & 6,7 & 6,7 \\
\hline banks and insurance companies & 1 & 3 & 6,7 & 6,7 & 6,7 \\
\hline conformity assessment bodies & & 3 & $4,5,6,7$ & $5,6,7$ & $5,6,7$ \\
\hline designers & & 3 & 4,7 & & \\
\hline builders and suppliers & & 3 & & & \\
\hline end-users & & 3 & & & 7 \\
\hline
\end{tabular}

The seven elements of the proposed framework address the various motivations and needs of the most relevant stakeholders of a building project, namely those briefly described below, which are based on a critical review of several publications that, somehow, address this subject (Becker, Foliente 2005; Bukowski 2003; Carlo et al. 2010; Garcia, Hanus 2004; Huovila 2007; ISO 10006; ISO 19011; ISO 21931-1; Lützkendorf et al. 2005):

- authorities and official bodies are provided with effective strategies to promote construction quality and protect end users (both individuals and the society) against non-conforming buildings and to acquire technical information concerning the exposure of buildings to the risk of damage (as well as that of the environment, property, health and life); these stakeholders are also provided with tools to communicate decisions and ensure compliance with its intents;

- owners and their representatives are empowered with the possibility to specify the levels of risk and/ or levels of building performance deemed acceptable and/or desired in earlier stages of the building process and also with a robust communication interface that facilitates interactions with the various participants throughout the different phases of the building project (designers, constructors, property managers, authorities, banks, insurance companies, technical controllers and auditors, etc.), which results in improved programming and procurement strategies and effective solutions to share the risks of building projects;

- banks and insurance companies are provided with adequate risk related information, which can support better initial lending decisions and more rigorous calculations of insurance premiums, which therefore may lead to higher revenues;

- conformity assessment bodies (independent third parties) benefit from a consistent, explicit and harmonized infrastructure to guide and support the conformity assessment activities that must be carried out throughout the various stages of a building project (technical control, technical audits, technical inspections, testing);

- designers are equipped with performance-based procedures that are easily incorporated into current engineering design and calculation methods, enabling them to comply and/or exceed applicable technical regulations or other type of demands;

- builders and suppliers are granted with an explicit understanding of the technical demands of owners and end-users of building projects and are thus capable to better comply or exceed mandatory and non-mandatory technical requirements; these stakeholders may also benefit from fewer barriers to innovation and from a proactive and preventive environment induced by conformity assessment activities (such activities value quality efforts, contribute to the mitigation of building defects and lead to lower post-construction reparation costs); and

- end-users can be presented with a warranty that the building fulfils the negotiated level of quality or performance or risk and are endowed with concise information that enables the comparison of concurrent alternatives in the building market.

The way in which these seven elements address the different phases of a building project is described in detail in Almeida (2011), namely by means of an example of application of the proposed framework to building structures. This example of application covers the building attributes addressed in parts 1 to 3 of the ISO 15928 standard for the description of performance of houses (structural safety, structural serviceability and structural durability). Further applications of the RM-PBB framework are envisaged for all other attributes addressed by the ISO 15928 standard (e.g. fire safety, operating energy, sustainability).

\section{Acknowledgments}

The authors acknowledge ICIST-IST Research Institute for supporting research at Florida International University, the Calouste Gulbenkian Foundation grant supporting research at Ryerson University, the Fulbright Commission 
for the award of a Fulbright/FLAD grant supporting research at UCDavis and the Portuguese National Science Foundation for the grants SFRH/BD/35925/2007 and SFRH/BD/39923/2007.

\section{References}

Almeida, N. M. 2011. Modelo de Gestão Técnica de Edifícios Baseada no Desempenho e no Risco: Concepção, Desenvolvimento e Exemplo de Aplicação a estruturas [Framework for Risk-Managed Performance-Based Building: Design, Development and Application to Building Structures]. PhD Thesis. Tecnico Lisboa, Universidade de Lisboa.

Almeida, N. M. et al. 2010a. A framework for combining risk management and performance-based building approaches, Building Research and Information 2(38): 157-174. http://dx.doi.org/10.1080/09613210903516719

Almeida, N. M. et al. 2010b. General framework for RiskManaged Performance-Based Building (RM-PBB), in Proceedings of the $18^{\text {th }} C I B$ World Building Congress, May 2010, Salford, 75-85.

Ang, G.; Groosman, M.; Scholten, N.; 2005. Dutch performance-based approach to building regulations and public procurement, Building Research \& Information 33(2): 107119. http://dx.doi.org/10.1080/0961321042000325345

Arbnor, I.; Bjerke, B. 2009. Methodology for creating business knowledge. $3^{\text {rd }}$ ed. California: Ingeman Arbnor \& Bjorne Bjerk. 464 p.

ASTM. 2000. Standards on whole building functionality and serviceability. $2^{\text {nd }}$ ed. West Conshohocken, Pa: ASTM International.

Becker, R.; Foliente, G. 2005. PeBBu $2^{\text {nd }}$ international SotA report. CIBdf. Mansi Jasuja. Final Report.

Bukowski, R. 2003. The role of standards in a performancebased building regulatory system. cib publication No. 290 . Strategies for performance in the aftermath of the World Trade Center, in Proceedings of CIB-CTBUH Conference on Tall Buildings. Kuala Lumpur, Malaysia: Task Group on Tall Buildings, CIB TG50.

Bukowski, R.; Hirano, Y.; Rackliffe, T. 2001. Standards linkages to a performance-based regulatory framework, Performance in Product and Practice - CIB WBC. Wellington, New Zealand, 1-9.

Carlo, A.; Filippo, M.; Emanuela, Q. 2010. The development of techniques to support the control activities during the carrying out of a building work: instruments to minimize the financial risk, in CIB World Congress. Salford: CIB.

CIB. 2004. Performance-based building regulatory systems. CIB TG37 Final Report. Rotterdam: Beth Tubs, International Code Council, CIB TG37.

Garcia, J.-P.; Hanus, F. 2004. Les contrôleurs techniques: constats et propositions d'évolution en matière d'habilitation. Conseil Général des Ponts et Chaussées. n. 2004-0030-01.

Gielingh, W. 2008. A theory for modelling of complex dynamic systems. Vol. 13. ITcon, 421-475.

Hattis, D.; Becker, R. 2001. Comparison of the systems approach and the nordic model and their melded application in the development of performance-based building codes and standards, Journal of Testing and Evaluation JTEVA 29(4): 413-422.

http://dx.doi.org/10.1080/0961321042000325345

Huovila, P. 2007. Measuring performance and value in manufactured housing, in $3^{\text {rd }}$ International Conference of Revaluing Construction 2007 - Crossing Boundaries, 8-10 October 2007, Copenhagen, Malmo.
IFIC. 1998. FRISCO - A framework of information systems concept. The FRISCO Report. Web edition: International Federation for Information Processing.

IRCC. 2010. Performance-based building regulatory systems principles and experiences, in Meacham, B. J. (Ed.). A Report of the Inter-jurisdictional Regulatory Collaboration Committee. 175 p.

ISO. 2010. Building trust - the conformity assessment toolbox. Genève: ISO Central Secretariat.

Lützkendorf, T.; Lorenz, D. 2006. Using an integrated performance approach in building assessment tools, Building Research \& Information 34(4): 334-356. http://dx.doi.org/10.1080/09613210600672914

Lützkendorf, T.; Speer, T.; Szigeti, F.; Davis, G.; Le Roux, P.; Kato, A.; Tsunekawa, K. 2005. A comparison of international classifications for performance requirements and building performance categories used in evaluation methods. Helsinki, in Proceedings of CIB 2005 Advancing Facilities Management and Construction through Innovation, 13 June 2005, Helsinki, Finland.

Meacham, B. 2004a. Performance based-building regulatory system: structure, hierarchy and linkages, Journal of the Structural Engineer Society of New Zealand 17(1): 37-51.

NKB. 1978. Structure for building regulations. Report No. 34. The Nordic Committee. Stockholm: The Nordic Committee on Building Regulations (NKB).

Olsson, R. 2006. Managing project uncertainty using an enhanced risk management process. Mälardalen University Dissertations - no. 34. Västerås: Mälardalen University Press.

Pilzer, D. 2005. Performance based building regulations. PeBBu Domain 7 Final Report. CIBdf.

Sousa, V.; Almeida, N.; Alves Dias, L. 2012. Risk management framework for the construction industry according to the ISO 31000:2009 standard, Journal of Risk Analysis and Crisis Response 2(4): 261-274. http://dx.doi.org/10.2991/jrarc.2012.2.4.5

Srdic, A.; Selih, J. 2011. Integrated quality sustainability assessment in construction - a conceptual model, Technological and Economic Development of Economy 17(4): 611-626. http://dx.doi.org/10.3846/20294913.2011.603177

Szigeti, F.; Davis, G. 2005. Performance based building: conceptual framework. Final Report. PeBBu Thematic Network.

Visscher, H.; Meijer, F. 2006. Building regulation for housing quality in Europe, in Proceedings of Workshop 19 Legal Aspects of Housing, Land and Planning, ENHR Conference - Housing in an Expanding Europe: Theory, Policy, Participation and Implementation, 2-5 July 2006, Ljubljana, Slovenia. $10 \mathrm{p}$.

Walker, G.; Pham, L.; Kose, S.; Watermeyer, R. 2010. Development of international performance parameters for single family dwellings, in $5^{\text {th }}$ Civil Engineering Conference in the Asian Region and Australasian Structural Engineering Conference 2010, 8-12 August 2010, Sydney, N.S.W.: Engineers Australia.

\section{Standards and guidelines}

ILO-OSH: 2001. Guidelines on Occupational Safety and Health Management Systems. Geneva: International Labour Organization, 2001. $27 \mathrm{p}$.

ISO 10006:2003. Quality management systems - guidelines for quality management in projects. Geneva: International Organization for Standardization, 2003. $32 \mathrm{p}$.

ISO 11863:2011. Buildings and building-related facilities Functional and user requirements and performance - Tools for assessment and comparison. Geneva: International Organization for Standardization, 2011. 23 p. 
ISO 14001:2004. Environmental management systems - Requirements with guidance for use. Geneva: International Organization for Standardization, 2004. 23 p.

ISO 15928-1:2003. Houses - Description of performance Part 1: Structural safety. Geneva: International Organization for Standardization, 2003. $16 \mathrm{p}$.

ISO 15928-2:2005. Houses - Description of performance Part 2: Structural serviceability. Geneva: International Organization for Standardization, 2005. $17 \mathrm{p}$.

ISO 15928-3:2009. Houses - Description of performance Part 3: Structural durability. Geneva: International Organization for Standardization, 2009. $14 \mathrm{p}$.

ISO 15928-4:2011. Houses - Description of performance Part 4: Fire safety. Geneva: International Organization for Standardization, 2011. $16 \mathrm{p}$

ISO 15928-5:2013. Houses - Description of performance Part 5: Operating energy. Geneva: International Organization for Standardization, 2013. $11 \mathrm{p}$.

ISO 19011:2011. Guidelines for auditing management systems. Geneva: International Organization for Standardization, 2011. $44 \mathrm{p}$.

ISO 21500:2012. Guidance on project management. Geneva: International Organization for Standardization, 2012. 36 p.

ISO 21931-1:2010. Sustainability in building construction Framework for methods of assessment for environmental performance of construction works - Part 1: Buildings. Geneva: International Organization for Standardization, 2010. 26 p.

ISO 31000:2009. Risk management - Principles and guidelines. Geneva: International Organization for Standardization, 2009. $24 \mathrm{p}$.

ISO 9000:2005. Quality management systems - Fundamentals and vocabulary. Geneva: International Organization for Standardization, 2005. $30 \mathrm{p}$.

ISO 9001:2008. Quality management systems - Requirements. Geneva: International Organization for Standardization, 2008. 27 p.

ISO Guide 27:1983. Guidelines for corrective action to be taken by a certification body in the event of misuse of its mark of conformity. Geneva: International Organization for Standardization, 1983. 5 p.

ISO Guide 73:2009. Risk management - Vocabulary. Geneva: International Organization for Standardization, 2009. $15 \mathrm{p}$.

ISO/IEC 17000:2004. Conformity assessment - Vocabulary and general principles. Geneva: International Organization for Standardization, 2004. $47 \mathrm{p}$.

ISO/IEC 17007:2009. Conformity assessment - Guidance for drafting normative documents suitable for use for conformity assessment. Geneva: International Organization for Standardization, 2009. $13 \mathrm{p}$.

ISO/IEC 17011:2004. Conformity assessment - General requirements for accreditation bodies accrediting conformity assessment bodies. Geneva: International Organization for Standardization, 2004. $21 \mathrm{p}$.

ISO/IEC 17020:2012. Conformity assessment - Requirements for the operation of various types of bodies performing inspection. Geneva: International Organization for Standardization, 2012. $18 \mathrm{p}$

ISO/IEC 17021:2011. Conformity assessment-Requirements for bodies providing audit and certification of management systems. Geneva: International Organization for Standardization, 2011. $44 \mathrm{p}$.

ISO/IEC 17024:2012. Conformity assessment - General requirements for bodies operating certification of persons. Geneva: International Organization for Standardization, 2012. 21 p.
ISO/IEC 17025:2005. General requirements for the competence of testing and calibration laboratories. Geneva: International Organization for Standardization, 2005. $28 \mathrm{p}$.

ISO/IEC 17030:2003. Conformity assessment - General requirements for third-party marks of conformity. Geneva: International Organization for Standardization, 2003. 5 p.

ISO/IEC 17040:2005. Conformity assessment - General requirements for peer assessment of conformity assessment bodies and accreditation bodies. Geneva: International Organization for Standardization, 2005. $13 \mathrm{p}$.

ISO/IEC 17043:2010. Conformity assessment - General requirements for proficiency testing. Geneva: International Organization for Standardization, 2010. $39 \mathrm{p}$.

ISO/IEC 17050-1:2004. Conformity assessment - Supplier's declaration of conformity - Part 1: General requirements. Geneva: International Organization for Standardization, 2004. 6 p.

ISO/IEC 17050-2:2004. Conformity assessment - Supplier's declaration of conformity - Part 2: Supporting documentation. Geneva: International Organization for Standardization, 2004. 2 p.

ISO/IEC 17065:2012. Conformity assessment - Requirements for bodies certifying products, processes and services. Geneva: International Organization for Standardization, 2012. 27 p.

ISO/IEC 17067:2013. Conformity assessment - Fundamentals of product certification and guidelines for product certification schemes. Geneva: International Organization for Standardization, 2013. $13 \mathrm{p}$.

ISO/IEC Guide 28:2004. Conformity assessment - Guidance on a third-party certification system for products. Geneva: International Organization for Standardization, 2004. 19 p.

ISO/IEC Guide 53:2005. Conformity assessment-Guidance on the use of an organization's quality management system in product certification. Geneva: International Organization for Standardization, 2005.ISO/IEC Guide 60:2004. Conformity assessment - Code of good practice. Geneva: International Organization for Standardization, 2004. $21 \mathrm{p}$.

ISO/IEC Guide 68:2002. Arrangements for the recognition and acceptance of conformity assessment results. Geneva: International Organization for Standardization, 2002. 8 p.

ISO/IEC TS 17022:2012. Conformity assessment - Requirements and recommendations for content of a third-party audit report on management systems. Geneva: International Organization for Standardization, 2012. 5 p.

ISO/PAS 17001:2005. Conformity assessment - Impartiality Principles and requirements. Geneva: International Organization for Standardization, 2005. $5 \mathrm{p}$.

ISO/PAS 17002:2004. Conformity assessment - Confidentiality - Principles and requirements. Geneva: International Organization for Standardization, 2004. 3 p.

ISO/PAS 17003:2004. Conformity assessment - Complaints and appeals - Principles and requirements. Geneva: International Organization for Standardization, 2004. 5 p.

ISO/PAS 17004:2005. Conformity assessment - Disclosure of information - Principles and requirements. Geneva: International Organization for Standardization, 2004. 4 p.

ISO/PAS 17005:2008. Conformity assessment - Use of management systems - Principles and requirements. Geneva: International Organization for Standardization, 2004. $12 \mathrm{p}$.

ISO/PAS 22539:2007. User guidance to ISO 15928 - Houses Description of performance. Geneva: International Organization for Standardization, 2007. 21 p. 
Nuno Marques ALMEIDA. He is an Assistant Professor at Technical University of Lisbon (IST) in the Department of Civil Engineering and Architecture, where he teaches Construction Management. He has practical experience in the planning, execution and control of public and private construction projects. His areas of interests include construction management, infrastructure asset management, quality and occupational safety and health management, technical control, performance-based buildings and risk management.

Vitor SOUSA. He is an Assistant Professor at Technical University of Lisbon (IST) in the Department of Civil Engineering and Architecture, where he teaches Construction Management. He has practical experience in the designing and modelling wastewater systems. His areas of interests include project management, in particular risk management, and hydraulic structures modelling, namely using computer fluid dynamic (CFD) codes.

Luís Alves DIAS. He is an Associate Professor at Technical University of Lisbon (IST) in the Department of Civil Engineering and Architecture, where he teaches Construction Management. He is the Vice-President of the ISSA-Construction Section and collaborator of the International Labour Organization (ILO - Program SafeWork) and the International Training Centre of Turin. His areas of interests include construction management, quality management, and occupational safety and health in construction.

Fernando BRANCO. He is a Full Professor at Technical University of Lisbon (IST), head of the Construction Sector in the Department of Civil Engineering and Architecture, where he teaches Construction Technology. He is President of the European Council of Civil Engineers (ECCE) and Vice-president of the International Association for Bridge and Structural Engineering (IABSE). He has co-authored five books and over 200 scientific papers and has been a Consultant for major Public Works in Portugal. 